\title{
Pemilihan Lokasi Situs Di Palembang: Tinjauan Ekologi
}

\author{
Budi Wiyana
}

Keywords: environment, settlement, ecology, site distribution

\section{How to Cite:}

Wiyana, B. Pemilihan Lokasi Situs Di Palembang: Tinjauan Ekologi. Berkala Arkeologi, 16(1), 33-39. https:// doi.org/10.30883/iba.v16i1.744

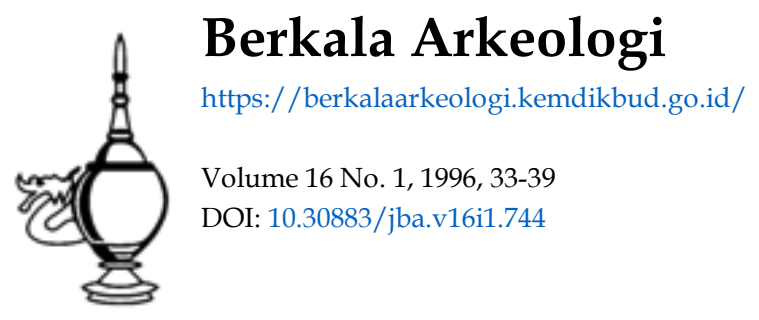

\section{cc) (i) (2)}

This work is licensed under a Creative Commons Attribution-NonCommercial-ShareAlike 4.0 International License. 


\title{
PEMILIHAN LOKASI SITUS DI PALEMBANG: \\ TINJAUAN EKOLOGI
}

\author{
Budi Wiyana \\ (Balai Arkeologi Palembang)
}

\section{Pendahuluan}

Kebudayaan merupakan usaha manusia untuk menyesuaikan dirinya dengan lingkungan alam. Lingkungan alam sebagai tempat tinggal manusia mempunyai peranan penting bagi kelangsungan hidup manusia. Peranan lingkungan alam terhadap manusia sudah tampak pada masa lampau, berdasarkan tinggalan arkeologis, termasuk situs arkeologi.

Situs arkeologi merupakan gambaran tentang aktivitas-aktivitas manusia masa lampau dan lingkungannya. Lingkungan situs ditentukan tingkah-laku individual manusia dengan mempertimbangkan berbagai faktor yang mempengaruhinya. Faktor-faktor yang berhubungan dengan kondisi alam dianggap merupakan salah satu faktor penting didalam pemilihan lokasi situs, disamping faktor- faktor lain, misalnya faktor ekonomis dan bahkan faktor politis.

Di dalam melakukan aktivitas-aktivitasnya, manusia memilih lokasi-lokasi yang disesuaikan dengan strategi subsistensinya. Dengan de-mikian, lokasi-lokasi situs arkeologi itu terjadi tidak secara acak, tetapi mempunyai pola yang ditentukan oleh manusia (Subroto, 1995).

Pemilihan lokasi suatu situs berhubungan juga dengan usaha meminimalkan pemakaian energi dan waktu didalam mengeksploitasi dan mendistribusi sumber-sumber subsistensi. Karena situs-situs tersebut menunjukkan aktivitas-aktivitas manusia, maka lokasi tempat keberadaannya dapat memberikan gambaran tentang lingkungan alam dan teknologinya (Judge, 1971: 38-44; Butzer, 1964: 337).

\section{Situs-situs di Palembang}

Sebagai daerah yang telah dihuni lama, Palembang menyimpan banyak situs, baik dari masa Klasik (Sriwijaya) maupun masa Islam (Kesultanan). Secara garis besar situs yang terdapat di Palembang dapat dibagi menjadi tiga daerah, yaitu situs di Palembang barat, tengah, dan timur (lihat lampiran peta) (Utomo, 1991; Wiyana, 1994, Purwanti dan Asih PT, 1995). 
Situs-situs yang terdapat di Palembang barat meliputi Bukit Siguntang, Kambang Unglen, Karanganyar, Kedukan Bukit, Kramat Pule, Ladangsirap, Talang Kikim, Talang Tuo, Tanjung Rawa, Gandus, dan Kambang Purun. Pagaralam, Candi Angsoka, Candi Walang, Benteng Kuto Besak, Masjid Agung, dan Museum Sultan Mahmud Badaruddin adalah situs-situs yang terletak di Palembang tengah. Sedangkan situs-situs di Palembang timur terdiri dari Telaga Batu, Sungai Buah, Sarangwati, Boom Baru, Kawah Tengkurep, dan Gedingsuro.

Dari sejumlah situs tersebut sebagian besar merupakan situs keagamaan dan bangunan. Situs-situs itu antara lain: Bukit Siguntang, Kedukan Bukit, Talang Tuo, Kambang Unglen, Kambang Purun, Karanganyar, Gandus, Candi Angsoka, Candi Walang, Pagaralam, Gedingsuro, Telaga Batu, Sarangwati, Air Bersih, dan Boom Baru Keberadaan situs keagamaan dan bangunan pada situs-situs di atas berdasarkan tinggalan arca, prasasti, lapik arca, struktur bangunan bata, candi, cetakan stupika, makara, stupika, dan tablet berisi mantra. Dari sejumlah tinggalan tersebut menunjukkan adanya kesamaan keagamaan, yaitu Agama Buddha (Mahayana) (Purwanti dan Asih PT, 1995).

Ada beberapa situs yang mengelompok atau terkonsentrasi pada suatu daerah tertentu, yaitu daerah sekitar Karanganyar di Palembang barat dan Daerah 3 llir di Palembang timur. Kedua daerah konsentrasi situs itu merupakan daerah yang terletak di kelokan atau meander Sungai Musi. Daerah sekitar Karanganyar terletak pada meander yang sangat tajam dan merupakan tempat bermuaranya Sungai Keramasan dan Ogan di Sungai Musi, sedangkan Daerah 3 llir tidak terlalu tajam. Situs yang terkonsentrasi di Daerah $\mathrm{Ka}$ - ranganyar berada di atas tanggul alam, hasil kibasan air Sungai Musi dan terletak di dekat rawa belakang atau backswamp. Jadi, daerah ini berada di atas lahan yang bebas banjir. Di sekitar Karanganyar juga terdapat "bangunan air" "Bangunan air" itu berupa kanal-kanal dan kolam-kolam buatan dengan pulau di bagian tengah kolam, sebagai hasil interpretasi foto udara tahun 1984

Di sekitar Daerah 3 llir terdapat situs yang dikelilingi oleh saluran air atau parit, yaitu Gedingsuro dan Sabokingking. Berdasarkan hasil penelitian melalui foto udara diketahui bahwa Situs Gedingsuro dikelilingi oleh saluran air. Saluran ini terletak di sebelah timur situs dan berhubungan dengan Sungai Musi. Meskipun demikian, bagian yang berdekatan dengan sungai tidak tampak jelas, karena tertutup oleh pemukiman 
Seperti halnya Situs Gedingsuro, di Situs Sabokingking ditemukan juga saluran air. Situs ini berada pada sebuah pulau kecil berbentuk segi empat yang sisi-sisinya tepat menghadap mata angin. Kolam yang mengelilingi pulau kecil itu dihubungkan oleh saluran dengan sungai-sungai kecil, yang merupakan anak Sungai Musi (Bakosurtanal dan Fakultas Geografi UGM, 1985 serta Rangkuti, 1989).

Sampai sekarang belum diketemukan atau tidak pernah ditemukan situs yang terletak di Daerah Hulu (Ulu). Semua situs yang ada ditemukan di sebelah utara Sungai Musi, atau menurut pembagian wilayah termasuk Daerah Hilir (llir). Daerah llir adalah daerah yang terletak di sebelah kanan Sungai Musi dilihat dari arah muara sungai, sedangkan Daerah Ulu terletak di sebelah kiri.

Di sebelah kiri Sungai Musi (Daerah Ulu) terdapat tiga sungai besar yang bermuara di Sungai Musi, yaitu Sungai Keramasan, Ogan, dan Komering. Sungai Ogan dan Keramasan bermuara di sekitar Daerah Karanganyar, sedangkan Sungai Komering bermuara di Daerah Sungai Gerong.

\section{Pembahasan}

Timbul dan tumbuhnya berbagai pemukiman di muka bumi ini didasari oleh berbagai macam faktor utama. Kemungkinan besar timbul dan tumbuhnya pemukiman tidak terbatas didasari oleh sebuah faktor semata. Berbagai faktor dapat sekaligus, sendiri- sendiri maupun bersama-sama mendorong pertumbuhan suatu pemukiman. Walaupun demikian terdapat satu hal yang merupakan titik persesuaian diantara berbagai faktor tersebut, yaitu basis kehidupan warga pemukiman yang bersangkutan. Basis kehidupan warga pemukiman sekali lagi memperhatikan formulasi tentang pemukiman, timbal-balik saling mempengaruhi dengan daerah dan kawasan di lingkungan pemukiman tersebut berlokasi (Kusumohartono, 1991: 33).

Secara umum peninggalan arkeologi yang terdapat di Kotamadya Palembang, terletak di dataran aluvial di pantai timur Sumatera bagian selatan. Daerah ini mempunyai topografi datar hingga berbukit rendah dengan ketinggian 2,5 hingga 25 meter di atas permukaan air laut. Situs-situs arkeologi di Palembang dan sekitarnya terdiri dari lahanlahan yang berbentuk: dataran banjir dan tanggul alam, dataran aluvial, rawa belakang, dan perbukitan rendah denudasional di Bukit Siguntang (Bakosurtanal dan Fakultas Geografi UGM, 1985).

Dari hasil penelitian Bakosurtanal yang bekerjasama dengan Fakultas Geografi UGM pada tahun 1985, dataran banjir dan tanggul alam terbentuk di sepanjang Sungai Musi sebagai hasil pengendapan 
material sungai pada saat banjir. Dataran aluvial mempunyai topografi datar hingga agak landai. Bentuk lahan ini relatif lebih tinggi dibanding dengan dataran banjir dan rawa belakang (backswamp), sedangkan lahan rawa belakang adalah bagian terendah yang terletak di belakang tanggul alam dan dataran aluvial. Oleh karena itu bentuk lahan ini mudah sekali tergenang air, baik pada waktu air Sungai Musi surut maupun pada waktu pasang.

Morfologi daerah Palembang dan sekitarnya terdiri dari dua satuan, yaitu dataran rendah dan perbukitan. Dataran rendah membentang luas dari sebagian kota Palembang ke arah utara, timur, dan selatan. Di sebagian besar dataran rendah tersebut terdapat rawa dan sungai kecil.

Satuan morfologi berikutnya adalah perbukitan yang terdapat di bagian barat-laut, mulai Bukit Siguntang menuju ke arah barat- laut sampai ke rangkaian Bukit Barisan. Sebagian besar tanahnya merupakan tanah pertanian yang kering (ladang dan huma) (Utomo, 1985).

Satuan morfologi sebelah selatan Sungai Musi lebih didominasi oleh dataran/rawa (lebak), sedangkan di utara Sungai Musi banyak terdapat dataran yang tinggi (talang) sebagai pengaruh adanya "ekor" Pegunungan Bukit Barisan di Palembang barat (Utomo dan Sartono, 1984; Tim Pemetaan dan Penelitian Geologi dan Arkeologi, 1984: 5).

Berdasarkan data di atas dapat dipakai untuk merunut dan mengungkap, mengapa situs-situs di Palembang terletak di sebelah utara Sungai Musi. Memang, penempatan situs (tempat tinggal, keagamaan, perbengkelan, dll.) pada suatu tempat tidak hanya disebabkan oleh satu faktor saja, melainkan bisa lebih dari satu faktor.

Kondisi Paiembang yang dilewati Sungai Musi dan terdapat banyak sungai kecil lainnya coba didekati dari pendekatan ekologi, dalam penempatan situs. Dengan pendekatan lingkungan (ekologi) akan terungkap, alasan pemilihan situs pada lokasi tertentu, disamping alasan lainnya.

Situs bangunan di Palembang, seperti halnya dengan yang terdapat di DAS Musi dan anak-anak sungai lainnya terdapat di bagian kanan sungai. Situs-situs yang terdapat di sebelah kanan DAS Musi di luar Palembang adalah Candi Teluk Kijing di Musi Banyuasin; Candi Babat, Modong, dan Tanah Abang di Muara Enim; serta Candi Bingin dan Lesung Batu di Musi Rawas. Alasan utama pemilihan situs keagamaan atau situs bangunan di Palembang pada sebelah kanan Sungai Musi adalah karena alasan keamanan (Soeroso, 1996: 7), terutama dari bahaya banjir atau genangan air.

Di sepanjang DAS Musi sangat rentan terhadap bahaya banjir, termasuk daerah Palembang. Untuk menghindari bahaya tersebut, 
maka dalam penempatan situs (terutama bangunan) perlu dipertimbangkan tempat-tempat yang aman dari bahaya banjir. Ternyata di bagian kanan Sungai Musi mempunyai ketinggian tanah yang lebih tinggi dibanding dengan di bagian kiri.

Di bagian kiri atau selatan Sungai Musi disamping lebih rendah, di daerah ini juga terdapat tiga buah sungai yang cukup besar (Sungai Komering, Keramasan, dan Ogan) yang bermuara di Sungai Musi. Dengan adanya ketiga sungai tersebut, maka daerah tersebut lebih rentan dari bahaya banjir, baik yang datang dari daerah ulu Sungai Musi maupun dari selatan (hulu Sungai Komering, Keramasan, dan Ogản). Keadaan ini diperparah dengan adanya pasang naik dan pasang surut dua kali sehari (diurnal). Sebagai akibat keadaan ini, maka di bagian kiri mudah terendam air dan memungkinkan menjadi daerah rawa yang luas. Sebagai konsekwensi logis dari pertimbangan ekologi, maka situs-situs di Palembang terletak di sebelah kanan Sungai Musi, karena di kanan lebih menguntungkan dibandingkan dengan bagian kiri.

Meskipun demikian, adaptasi terhadap lingkungan situs sudah diperhitungkan pada waktu pembuatan situs, misalnya adaptasi lingkungan di daerah Karanganyar, Gedingsuro, Sabokingking, dan sekitar Museum Badaruddin.

Di daerah Karanganyar, Gedingsuro, dan Sabokingking upaya untuk mengatasi genangan air dilakukan dengan membuat kanal-kanal atau saluran-saluran. Sedangkan di Museum Badaruddin upaya tersebut dilakukan dengan penataan kayu sebagai pemantap fondasi bangunan. Penataan kayu sebagai pemantap fondasi tetap dibutuhkan walaupun proses pemadatan rawa telah berlangsung sejak berdirinya konsentrasi bangunan bertiang di areal itu pada fase sebelumnya (Kusumohartono, 1992: 39-40).

Upaya adaptasi lingkungan daerah rawa atau genangan air untuk pendirian bangunan (candi) pada zaman dahulu, juga dilakukan di daerah Kalimantan Selatan (Kusumartono, dan Suhadi, 1996).

\section{Penutup}

Kebudayaan merupakan usaha manusia untuk menyesuaikan diri dengan lingkungannya, termasuk dalam hal mendirikan bangunan atau situs keagamaan. Dalam mendirikan bangunan dipengaruhi oleh beberapa faktor, misalnya karena faktor ekologi, ekonomi, politis maupun religi.

Penempatan situs di daerah Palembang dapat didekati dari pendekatan ekologi. Berdasarkan data yang ada, situs-situs arkeologi 
di Palembang semuanya terletak di sebelah kanan Sungai Musi Ternyata berdasarkan ketinggian tempat, bagian kanan sungai lebih tinggi dibandingkan dengan bagian kiri.

Disamping itu, di bagian kiri terdapat tiga buah sungai yang cukup besar dan bermuara di Sungai Musi. Dengan bertemunya ketiga sungai tersebut dengan Sungai Musi, maka bagian kiri mudah tergenang air $\mathrm{Hal}$ ini diperparah dengan adanya pasang naik dan pasang surut dua kali sehari (diurnal). Kondisi daerah yang selalu tergenang air kurang memungkinkan sebagai pendirian situs, tentunya pilihan lebih tepat pada daerah yang tidak selalu tergenang air (bagian kanan sungai).

Ternyata pendekatan ekologi dapat dilakukan untuk mengętahui alasan pendirian suatu bangunan atau situs. Dengan pendekatan ekologi telah berhasil diketahui penempatan situs masa Hindu-Buda di Daerah Yogyakarta (Mundardjito, 1993) dan pola persebaran situs bangunan masa Hindu-Buda di wilayah Batujaya dan Cibuaya (Soeroso, 1995).

\section{Kepustakaan}

Bakosurtanal \& Fakultas Geografi UGM,1985,Laporan Pemetaan Terintegrasi Kepurbakalaan Sriwijaya Yogyakarta (belum terbit)

Butzer, Charles A., 1964, Environment and Archaeology: An Introduction to Pleistocene Geography, Chicago:EP. Dutton \& Co Inc

Judge, W. James, 1971, An Interpretative Framework for Understanding Site Locations, The Distribution of Prehistoric Population Agregates, Anthropological Reports I, edited by George J. Gunerman, Prescott College Press, hal. 38-44.

Kusumartono. Vida V. dan Suhadi M., 1996, Catatan Singkat tentang Candi Laras, PIA VII, Cipanas

Kusumohartono,Bugie.1991,Pendekatan Lingkungan dalam Rekonstruksi Pertumbuhan Trowulan Kuno: Suatu Pemikiran Induktif, Buku Acuan Kuliah IFSA, Jakarta: Puslit Arkenas, hal. 30-40.

Kusumohartono,Bugie., 1992, Potensi Lingkungan Regional dan Pertumbuhan Kuna di Palembang Himpunan Hasil Penelitian Arkeologi di Palembang Tahun 1984-1992 hlm. 27-43 Jakarta Puslit Arkenas. 
Mundardjito, 1993, Pertimbangan Ekologi dalam Penempetan Situs Masa Hindu-Buda di Daerah Yogyekarta: Kajian Arkeologi Ruang Skala Mokro, Disertasi, Jakarta: Universitas Indonesia

Pumanti. Retno \& Asih PT. Eka, 1995, Situs-situs Keagamaan di Palembang: Suatu Tinjauan Kawasan dan Tata Letak, Seminar Manusla Dalam Ruang: Studi Kawasan Dalam Arkeologi, Yogyakarta: Balai Arkeologi Yogyakarta.

Rangkuti. N., 1989, Strukfur Kota Sriwijaya di Daerah Palembang. PIA $V_{\text {, hal }}$ 161-177. Jakarta: Puslit Arkenas.

Soeroso, 1995. Pola Persebaran Situs Bangunan Masa Hindu-Buda di Pesisir Utara Wilayah Batujaya dan Cibuaya, Jawa Barat: Tinjauan Ekologi, Tesis, Jakarta: Universitas Indonesia

Soeroso, 1996. Pola Persebaran Situs Bangunan Masa Hindu-Buda di Wilayah Sumatera Selatan, PIA VII, Cipanas.

Subroto, P. (1995). Pola-Pola Zonal Situs-Situs Arkeologi. Berkala Arkeologi, 15(3), 133-138. https://doi.org/10.30883/jba.v15i3.685

Tim Pemetaan dan Penelitian Arkeologi dan Geologi, 1984, Laporan Penelitian Geologi dan Arkeologi Palembang (belum terbit).

Utomo, Bambang.8., 1985, Renelitian Arkeologi di Daerah Lembah Sungai Musi, Palembang, REHPA, hal. 151-162. Jakarta: Puslit Arkenas.

1991, Laporan Penelrian Arkeologi Palembang 1984-1990, Jakarta: Puslit Arkenas

Utomo, Bambang Budi. dan Sartono, 1984, Laporan Penelitian Arkeologi dan Geologi Palembang 1984 (belum diterbitkan)

Wiyana, Budi. 1994, Petunjuk Singkat Kekunaan di Kodya Palembang, EHPA, Palembang. 